\title{
THE CONCEPT OF PEACE IN ISLAM AND ITS RELEVANCE TO INTERNATIONAL RELATIONS
}

\author{
Rizki Dian Nursita \\ Univeristas Islam Indonesia \\ Email: rizki.dian.nursita@uii.ac.id \\ Ahmad Sahide \\ Universitas Muhammadiyah Yogyakarta \\ Email: ahmadsahideumy@gmail.com
}

\begin{abstract}
Islam is often described as a religion that emphasizes the use of violence in its da'wah method. The stereotype is formed by a number of literature and media that depicted Islam as a religion of violence. This paper aims to analyze the causes of stereotype against Islam, and provides an overview of the concept of peace in Islamic perspective, and seek the relevance of the concept of peace in Islam to the study of conflict and peace in international relations. Through some literature research, the author finds that the stereotype is caused by the gap in the discourse on war and peace in Islam, thus the discourse related to the peace in Islam needs to be buzzed. Unlike the two mainstreams in International Relation Studies (Realism and Idealism), al-Quran, as the primary source of Islamic teaching, describes that a human is basically both keen to cooperate and prone to conflict, and favoring to managing the conflict through peaceful settlement. Three terms-as-silmu, as-shulhu, and al-amanu are used to conceptualize the three levels of peace in the Quranic perspective.
\end{abstract}

Keywords: As-silmu; Islam; International Relations; Peace; War.

\section{INTRODUCTION}

The $11^{\text {th }}$ September attack has became a major momentum that influenced a number of changes in the international relations discourses. The concept of security which is initially understood by realists as states' capacity to deal with threats from other countries in the midst of international anarchy, it must immediately be doubted after $11^{\text {th }}$ September attack. It also has brought up a number of new terms in international relations, such as terrorism, terrorist; as a new actor in international relations, and global war on terrorism; the United States foreign policy which emerged in the Bush administration has also affected the foreign policy of countries around the world. 
Several media have been involved in the formation of stereotypes of global society towards Islam and the Middle East. Famous newspapers and electronic media, such as $\mathrm{CNN}$ and $\mathrm{BBC}$ have intensively broadcast news and stories about the Middle East during the Gulf War I and Gulf War II. Internal conflict has also been a major trend in recent years. Unfortunately, statistics seemed to support stereotypes. Some countries in the Islamic World, such as Pakistan, Libya, Sudan, Ukraine, Yemen, Somalia, Afghanistan, Iraq, and Syria have been identified as countries with the lowest security index, even Saudi Arabia, Egypt, Turkey, and Palestine are on the alert status (GPI, 2016).

The relation among Islam, war, and terrorism is also often depicted in a number of fictions. The Three Kings portrays the story during the Gulf War I. The Hurt Locker tells the story of explosive disarmament missions in the Second Bay War. We also find other movies, such as Homeland movie, Zero Dark Thirty, United 93, and a number of Western films portray the story of alQaeda and Osama bin Laden's actions that might be considered as the threat to the national security.

Literature about 'Islam and War' and 'Islam and Terrorism' seem to be more popular compared with 'Islam and Peace'. Some books which offer the discussion on 'Islam and Peace', start the discussion with the concept 'War' in Islam. As if the concept of peace in Islam is valid if Islam is acceptable as both religion and a political system. The term of jihad in Islam seems to be understood as 'Jihad bil anfus' (by risking life) or 'Jihad bis sayf' (with sword, violence). The concept of jihad is also often equated with the concept of holy wars that have occurred in the West (Firestone, 1999). Although the concept of jihad also includes wars and risking the lives, etymologically, the term of jihad does not take root from the word war like 'qital' or 'harb', rather it has a broader spectrum. Jihad is probably the most controversial and emotive word that the West associates with Islam today; not a day goes by in the media when the word is not invoked, either by the jihadis themselves or critics of Islam (Fuller, 2010).

The stigma of Islam as a common threat has contributed to the emergence of Islamophobia, mainly in the era of George Walker Bush after September attack (Sahide, 2018). In fact, the Middle East which is always associated with 'Islam' is not always lulled by wars and may be less compared to the other regions in the world. According to the war historian, Quincy Wright, the number of wars that took place around the world from 1484 to 1945 shows that of 278 wars, 187 wars occurred in Europe while 91 battles took place in other regions (Firestone, 1999).

Most of the stigma of Islam often begins with methodological issues. Western 
scientists or perhaps orientalists who are not accustomed to Islamic tradition often regard Islam as a religion that merely teaches violence by simply taking a number of relevant verses and hadiths. The research is also supported by references to the history of Islam which tells several cases of communal violence and political conflict. So they come to the conclusion that Islam is a religion that basically justifies acts of violence due to differences in beliefs and politics (Nimer, 2001).

Primary sources in Islamic law, both the Al-Quran and Sunnah have encouraged the attitude of peace. Even the term of 'Islam' itself has its root to the verb 'salima' and the noun 'salam' means salvation and peace. Al-Qur'an encourages Muslims to have good behavior toward followers of other faiths (Yunus 10:99), to settle disputes (al-Hujurat 49: 9), to know each other (alHujurat 49:13), and to cooperate in goodness, not enmity. The concept of peace in Islam may get less spotlight in Islamic political literature, but it is actually very much mentioned, even written with very detailed in the books of adab (ethics) of social life.

This paper tries to enhance the idea of peace in Islam which has so far been neglected, without disproving the existence of the concept of war in Islam. This paper discusses the gap that occurs in the discourse between war and peace in Islam, the basic assumptions of Islam on peace compared with two mainstreams in international relations, the classification of the concept of peace in Islam and its relevance to the contemporary peace studies.

\section{WAR AND PEACE IN ISLAMIC PERSPECTIVE}

This section attempts to provide an overview of the inequality between the discourse on war and peace in Islam. The recent literature on Islamic politics tells more about the use of violence, wars, the treatment of combatants and prisoners of war, international law, and so on. Nonetheless, the classical Islamic literature has actually dealt with these concepts, and some classical scholars have been asked for judgements or fatwas related to war and peace in Islam (Nimer, 2001).

One of the classical scholars who was also the disciple of Imam Abu Hanifa, Muhammad bin al-Hasan as-Syaibani was one of the classical scholars of the eighteenth century who has involved in the field of international law studies; eight centuries earlier than Hugo Grotius; the father of international law from the West. Syaibani's masterpiece, 'Siyar'; 'Siyar as-Shagir' and 'Siyar al-Kabir' tell a lot about fatwas from Abu Hanifa and Syaibani himself. Siyar which is the plural form of 'Sirah'; which not only means 'history', but also 'journey', 
then simply interpreted by modern.

The book of Siyar contains a set judgements that guides Muslims interaction with non-Muslims; whether in a state of war or peace, whether interaction among individuals or in a state level; interaction between Darul Islam and Darul Kufr within the territory of Islam as well as outside; and interaction in the particular situations such as apostasy, rebellion and piracy (Munir, 2012). The book of Siyar was later reconstructed by a number of Muslim scholars, one of them was Muhammad Abu Zahra in his Syarh Kitab as-Siyar al-Kabir, as well as prominent orientalists such as Majid Khadduri. The work of Majid Khadduri which contains the introduction and translation of the Book of Siyar written in 1966, 'The Islamic Law of Nations Shaibani's Siyar' has been reviewed widely by Western scholars.

Perhaps we may find few writings in the Islamic classical literature that specifically address the study of international relations. The book of Siyar could be seen as a positive thing, although the fatwas were not codified as a set of rules. We can see that Siyar has been written based on the idea that interaction among nations is conflictual; between Islam and kufr or Islam and rebels. Peace in the Islamic classical literature is understood as negative-peace or the absence of war; between Islam with kufr, or between government and bughot or rebel; and when the dhimmis are at 'safe conduct', or 'aman' .

The legal view on peace and violence in the classical period was articulated and applied on the basis of maqâsid as-shariah; teachings or purpose (intent) of the whole Islamic law which aims to protect religion, life, humans' reason, humans' property, their honor, and descents. These six points of purpose are considered as fundamental needs or dharuriyat in Islam. Maqashid is used by considering context or fact that occur in a particular society.

It should be noted, that in Islam political conflicts set forth in a juridical decision or fatwas, remain a political conflict. They have never been extended to religious wars, such as the war between Islam and Christianity, Judaism, Hinduism or any other religions that Islam has ever encountered in history. The juridical judgment is certainly in accordance with the conditions faced by Muslims; fatwa of an expert that allows the use of force against a pagan ruler in certain conditions, is not a reason to attack a neighbor who has different beliefs (Nimer, 2001), nor it is a holy war with the aim of killing certain people with different beliefs.

Such inequality also occurs in contemporary Islamic studies. Orientalists such as Majid Khadduri had earlier issued War and Peace in the Law of Islam in 1955, several years before the publication of 'The Shaibani's Islamic Law of Nations 
Siyar. This book describes both War and Peace concepts comprehensively in one book. However, the discussion of the peace is placed in the third chapter after the war, and it still contains discussions about the treatment of Islam against other religions, dhimmis, peace agreements, arbitration and neutrality; despite there is also a part discusses about international diplomacy and trade (Khadduri, 1966). This book became the most frequently used reference by academics in explaining the concept of war and jihad in Islam. On the other hand, this book is also often regarded as a book that has justified stereotypes about Islam; that Islam is a religion of violent doctrines and terrorism.

The work of Abu Sulayman 'Towards an Islamic Theory of International Relations' published in 1987 has shown a novelty in the discourse of international relations of Islamic perspective. Although Abu Sulayman did not exclusively discuss the concept of peace in Islam, at least it has raised some peace-related concepts, such as tolerance, cooperation and mutual support, diplomacy and building alliances (Abu-Sulayman, 1993). Similarly, Abu Zahra in his work 'Al-'Alaqah ad-Dauliyyah fi-l-Islam' or 'International Relations in Islamic Perspective' explains the normative aspects of international relations; international relations are bound by values such as dignity, the unity of people, encouraging Muslims to help each other, and tolerance (Abu-Zahrah, 1995). However, these books are still infrequently used as the reference by contemporary scholars.

Indonesia may have become one of the examples of the spread of Islam through peaceful means. According to Abdullah bin Nuh, the spread of Islam in Southeast Asia did not occur in the 13th century AD. Historical evidence from China and some Muslim settlements in Indonesia show that Islam come to Indonesia since the 7 th $\mathrm{AD}$ through the preachers and traders. People in the Arabian Peninsula have established trade cooperations with various countries, such as Africa, India, Southeast Asia, and East Asia. These relations have occurred long before Mohammed's prophecy. Arabian merchants have become the intermediaries between these countries and European merchants. It is estimated that Islam has penetrated to the Southeast Asia since the 7th century $\mathrm{AD}$, or in the second year of hijriyah. This estimate is supported by the findings of T.W. Arnold, which shows that Muslim traders have been in Sailan and Sri Lanka since the second century of Hijriyah (Suryanegara, 2017).

According to Karen Armstrong, Western assumptions related to Islam; Islam as a religion that teaches violence and jihad considered as twin brother of the crusade, such assumptions can not be separated from the trauma of the West against the wars occurred in the Middle Ages (Armstrong, 2001). Before the era of colonialism, Indonesia which was far away from the story of the 
holy war in the West, certainly had a different response to a comprehensive religious teaching; Islamic belief which is not only understood as ritual, but also provides security and social and political order.

The spread of Islam in Indonesia has been done through diverse concepts of dawah, whether da'wah through diplomacy with local rulers, trade, assimilation, marriage, and sufism; considering Muslims are obliged to involve in the da'wah regardless their status and occupation. Yet, both the Islamic World and the West are often fixated on the heroic stories that are identical to warfare, but ignorant of the stories of how the Messenger and his companions, as well as some political leaders sought to create the peace.

\section{CONFLICT AND HUMAN NATURE}

Two mainstream in international relations, both Classical Realism and Classical Liberalism or Idealism cannot be separated from the fundamental thinking about the nature of human being. The emergence of Realism and Idealism both started from assumptions about the nature of human beings. Realists see that human nature is selfish, and interaction among people is conflictual. Thus, realists tend to have a pessimistic and skeptical view about cooperation and peace in international relations (Pettiford, 2015., and Heywood, 2011).

Within the state, the selfishness within a human being is limited by government. Whereas in international relations, the selfishness that exists in human beings may unleash the worst potential of human nature, thus forming an anarchic structure (Donnelly, 2005). Morgenthau as a classical realist scholar saw that the state was the first institution to ignore the human values to gain the power. Meanwhile, according to neorealists, international violence is not the impact of human egoism, but a social phenomenon that is formed due to the anarchic international environment (Guzzini, 2003). The state is seen as its own organic structure, which has its own interests and strengths, not merely as a humandriven instrument.

On the contrary, liberalists see people are bound to human virtue. The conflict that occurs between people will not become a problem, if the cause of the conflict can be identified, then the problem can be solved. According to Kant, humans are not always associated with selfishness, greed, and aggression. Humans are naturally affectionate and able to distinguish between good and bad (Pettiford, 2015). Liberalists see that war is not caused by human nature or the structure of the international system, rather war is the product of social interaction (Burchill, 2005).

Discussion about human beings becomes very important in the study of 
international relations of Islamic perspective. Regarding human nature, Islam is neither realistic nor idealistic. However, it should be noted that the discussion is not intended to build a synthesis between the two mainstream debates; as the English School was born to become via media between Realism and Liberalism (Linklater, 2005). Islam is a religion that encourages wasathiyah, as it has been mentioned in the Qur'an, that the character of Muslims is ummatan wasathan (al-Baqarah 2: 143). Wasath is a stand-alone position, neither side nor both. Wasathiyah attitude does not mean 'ghuluw' or exaggeration (al-Maidah 5:77). A man who is wasathiyah will be able to understand reality, priority, nature or sunnatullah, and comprehend religious texts comprehensively (Tamam, 2017).

Islam recognizes the human nature equally, that man also has the potential to do good and evil. As in the word of God in sura as-shams; "And by the soul (nafs) and the perfection of His creation, He inspired the soul what is wrong and what is right for it." (as-Shams 91:7-8). Refer to Tafsir Ibn Kathir, what is meant by the perfection of creation is that Allah has directed man to a righteous nature. As the words of Surah Ar-Rum Allah says, "Then face your face with the righteousness of Allah (Allah), (on) the nature of Allah Who created man according to the fitrah. No change in the nature of Allah." (ar-Rum 30:30). But God then inspired man to the way of good and evil, as it is mentioned by Mujahid, Qatadah, ad-Dhahak, as-Tsauri (Katsir, 2004a).

In the hadith, it is narrated that someone who asked the Prophet Mohammed, "O Messenger of Allah, how do you think about what is done by human beings whom they laboriously overcome. Is it fate that has been set upon them, or is it something that they receive from what their Prophet said to them, then reinforced with the argument?" So the Messenger of Allah answered: "No that is the thing that has been established for them. "The man asked again,"Then what is the use of charity?" The Prophet replied, "that whoever is created by God to do one of them, then Allah prepare it for it, as it is said in the Book of Allah: and the soul and the consummation of it, then Allah inspires the soul the right and wrong path." (Katsir, 2004).

In Islam, the first conflict accompanied by use of violence that occurred in human history has been narrated in the Qur'an. That is the story of the son of Adam, when Qabil and Abel compete each other to be the best, as well as fighting for a potential spouse. As it is hinted in Surah al-Maidah, "his lust encourages the killing of his brother, so he kills him, and he is among the losers" (al-Maidah 5:30). Conflict is also mentioned in the Quran in a number of terms and levels, ranging from enmity (az-Zumar 39:31), disputes (Ali-Imran 3:103 \& 105), disagreements (an-Nisa 4:59), and wars (Muhammad 47:4), (al- 
Baqarah 2:217), (al-Anfal 8:57).

Although Islam exposes the human nature to do good and evil. However, it does not mean that evil deeds become permissible in Islam; including violence, crime, and hostility. As it is mentioned in the verse after that, "it is indeed a lucky man who purifies the soul, and indeed he fails who corrupts it." (as-Shams 91:9-10). According to Qatadah, this verse explains it is to be fortunate that one who purifies himself from a disgraceful attitude and contemptible things; is considered obedient to Allah, as it was narrated by Mujahid, Ikrimah, and Said bin Jubair (Katsir, 2004a).

The striking difference between Islam and other paradigms is the concept of after life, and the concept of reward and sin or reckoning. In Islam, all human deeds can not be separated from the hisab and will be accounted for in the hereafter. As Allah says in the Quran Surah az-Zalzalah; "Whoever does good deeds of zarrah, he will see the reward, and whoever does the evil weighing of zarrah, will surely get his reward" (az-Zalzalah 99:7-8).

We may often hear a proverb, "My country, right or wrong" that indicates state's superiority as an actor that has the immunity to do anything to defend its national interest. Realists separate national and international negotiations with morality. Thus, diplomacy in the classical era is full of hypocritical actions and lies (Iqbal, 2000).

In Islam, international relations are not merely inter-state relations, but human beings as the main actors who run the state; as well as other entities considered as actors in international relations; international organizations, corporations, interest groups. Man as an actor who runs the state and other relevant entities in international relations, thus all of activities including social and political cannot be separated from the reckoning, and cannot be apart from the norms, values, and divine rules that bind people from acts that can cause hostility, conflict, and damage.

\section{THE CONCEPT OF PEACE IN ISLAM}

Etymologically, the word Islam is closely related to the salvation, peace, and submission. In Arabic, the word Islam itself is rooted to the verb سلم (salima) and mashdar or noun taken from the verb السلام (as-salaamu) meaning نجام (sala) (najaa) or "to be safe" or "salvation". The word سلم (salima) can also turn into (saalama) which is synonymous with صالح (shaalaha) or "reconciled", and the noun السلم (as-silmu) also has the same meaning as الصلح (as-shulhu), which means peace; as it is found in the phrase أنا سلم لمن سالمني وحرب لمن حاربني (ana silmun liman saalamani wa harbun liman haarabanii) which means "I make 
peace to those do the same, and fight against those who fight me". Whereas the إظهار الخضوع و القبول لما أتى به محمد, الدين الذي جاء has the meaning of الإسلام word or submission and full acceptance of religion conveyed by Muhammad (Ma'luf, 2007).

The term "silmun" is also contained in the Qur'an, as Allah has commanded the believers, "O ye who believe, enter too silmi (Islam) completely, and do not follow the paths of shaitan" (Al-Baqarah 2:208). This verse encourages Muslims to the peace and to perform good deeds and all kinds of virtues, as it was stated by Qatadah and Mujahid (Katsir, 2004b).

Peace in Islam can be interpreted by both positive and negative peace. According to Galtung, positive peace indicated by cooperation, equality, peaceful culture, and dialogue. While the negative peace is the absence of violence, or the condition when the conflict actors are in a truce, withdraw from violence (Galtung \& Fischer, 2013). Negative peace is needed to prevent violence among parties, disputes, or further violence and international conflict. Positive peace or substantive peace provides a broader view to address the causes of a conflict (Nimer, 2001).

The term positive peace is associated to human values and the application of a peace culture in life. Allah is known as Ar-Rahman or The Most Beneficent and the Al-Raheem or The Most Merciful. So human beings as His creations certainly can not be separated from those two characters. As it is mentioned in the Qur'an, "Indeed, those who have believed and done righteous deeds - the Most Merciful will appoint for them affection" (Maryam 19:96). "Perhaps Allah will put, between you and those to whom you have been enemies among them, affection. And Allah is competent, and Allah is Forgiving and Merciful." (AlMumtahanah 60:7).

Therefore, positive peace is substantial in Islam. The values found in positive peace is the basis of morality (akhlaq) in Islam that should be attached to each individual. So the real peace can exist. According to Abu Zahra, there are ten principles of mu'amalah or relationship among people, such as respect for mans' dignity (al-Isra '17:70); unity (al-Baqarah 2:213) (Ali-Imran 3:103); cooperation in good deeds or humanity (al-Maidah 5:2), tolerance (al-Kahf 18:29) (al-Kafirun 109:6), freedom (to decide fate and religion) (al-Baqarah 2: 256) (Al-Rahman 55:60); justice (al-Hujurat 49: 9); equality in human relationships (al-Hujurat 49:13) (al-Balad 90: 11-13)) ; integrity (al-Maidah 5:1) (an-Nisa 4:58); and compassion (Maryam 19:96). These principles are not just principles that bind to individuals or intergroup relationships, but also the state, since the state is a human-driven political entity. 
Islam also recognizes the concept of negative peace; through conciliation and peace-making efforts in resolving conflicts among individuals or groups, to ensure the positive peace among communities can be formed. As it was stated, that the term السلم (as-silmu) which has the same root as Islam, it is also equivalent to الصلح (as-shulhu) which means peace, and al-ishlah means conciliation, peacemaking, making a change or reformation, as well as the integrity to the truth (Nimer, 2001). The word الصلح (as-shulhu) is originally derived from the one-level verb صلح (shaluha) which means the opposite of destruction, which then becomes the second verb, صالح (shaalaha) which means antonym of enmity (Ma'luf, 2007). The term as-shulhu is also contained in the words Darus-Shulh, a term for a country that does not join Darul-Islam but chooses to make peace with it.

Islam emphasizes the importance of creating peace among people. The virtue of peace-making or al-ishlah has been mentioned in a number of verses of the Qur'an and hadith. In an-Nisa' Allah says, "No good is there in much of their private conversation, except for those who enjoin charity or that which is right or conciliation between people. And whoever does that seeking means to the approval of Allah - then We are going to give him a great reward." (an-Nisa 4:114), in al-Hujurat, "And if two factions among the believers should fight, then make settlement between the two. But if one of them oppresses the other, then fight against the one that oppresses until it returns to the ordinance of Allah And if it returns, then make settlement between them in justice and act justly. Indeed, Allah loves those who act justly." (al-Hujurat 49: 9), then in Surat al-Anfal, Say, "The (decision concerning) bounties is for Allah and the Messenger." So fear Allah and amend that which is between you and obey Allah and His Messenger, if you should be believers" (al-Anfal 8: 1). In a number of hadiths, Messenger of Allah (s) said, "May I tell you something better than fasting, prayer and alms?" The Companion replied, "Yes." He said, "Reconcile the relationship (two warring people), because the destruction of the relationship is the cutter. I do not say cutting hair, but cutting off religion." The hadith shows that peacemaking not only counts as a virtue, it also reduce unnecessary hostility and damage.

In order to ensure the absence of violence, Islam also promotes security. The word الأمن (al-amnu) means serenity and peace, while الأمان (al-amaanu) also has other meanings, ie العهد و الحماية و الذمة (al-'ahdu, al-himaayah, adh-dhimma); it means covenant; protection, and guarantees (Ma'luf, 2007). It also can be understood as the security from the violence (Nimer, 2001). These words also have their roots to the word الإيمان (al-iman) or belief.

State's security is essential to maintain the survival of human life. As the prayer of Prophet Ibrahim in the Qur'an "And remember when the Prophet Ibrahim 
prayed "My Lord, make this a secure city and provide its people with fruits whoever of them believes in Allah and the Last Day." (Al-Baqarah 2:126), then in other verse, "My Lord, make this city (Makkah) secure and keep me and my sons away from worshipping idols." (Ibrahim 14:35). Security is also related to trusworthy issues, or beliefs. Even trusworthy is part of the faith (HR Ahmad), as the non-traditional security concept also puts 'freedom from fear' as one of the security indicators.

Al-Qur'an contains wisdom and lessons for people who use their reason (Yusuf 12:111). The use of peaceful means in da'wah has been raised in a number of Qur'anic verses which tell the story of the previous prophets. The Qur'an has told of how the earlier prophets established relationships with those who rejected their preaching. Still, people of 'Ad are mentioned as 'brothers' of the Prophet Hud, even though they refuse Islam (Hud 11:40). The Qur'an has also mentioned Thamud who rejected the Prophet Salih, and the people of Noah as 'brothers'. Allah also commanded Moses to deliver da'wah to Pharaoh with 'qaulan layyinan' or a gentle word (Thaha 20:43-44). There are also many sunnah and sirah have narrated about how Prophet Mohammed has built good relationships with people; ethics towards parents, children, neighbors, women, and other believer, ethic in assembling, speaking and expressing opinions, and other ethics that encourage Muslims to remain virtuous toward others.

It is also important to understand and prevent the potential conflict, Latent conflict often occurs within society with various groups and ethnicities. Thus, even before the conflict arose, Mohammed has reconciled between Muhajirin and Ansar so that love compassion and altruism have spread among them; in other words it was a positive peace. The story of how the Prophet Mohammed and the Companions negotiated with Medina Jews and issued Medina Charter, as well as the truce with the Quraysh tribe in the Hudaibiyah Treaty (Lapidus, 2002). They are both examples of negative peace.

\section{CONCLUSION}

Islam often faces negative stereotype as a religion of violence. The concept of jihad is often associated with holy war and terrorism. So, Islam is always identified with terrorism (Pratt and Woodlock, 2016). The stigma of Islam, as a religion of violence is the result of gap between the discourses on Islam. The concept of war in Islam perspective is more often discussed, compared to the concept of peace.

Unlike the two mainstream in international relations, Realism and Liberalism. 
Islam sees a balance in the human nature. Humans are naturally love to cooperate and do good deeds, and have tendency to conflict and do evil deeds. Nevertheless, it does not mean that Islam justifies such tendency to use violence and wickednesss in politics, so that international relations become very rational and value-free. Human beings by nature are political creature who run the state, thus creatures are inseparable from divine rules, and Islam prevent the conflict with impulse to do good deeds and to create the peace; both negative and positive peace.

The concept of peace in Islam consists of as-silmu, as-shulhu, and al-amaanu. It is obliged for believers, to fully throw themselves in goodness (as-silmu). Such obligation binds all Muslims in every condition. A believer or a Muslims is not only obliged to perform mandatory worship, but also responsible to incorporates Islamic values in a kaffah or perfect way in social, political, economic, and any other aspect; such as mutual respect, unity, cooperation, tolerance, respect human rights, righteousness, justice, to be equitable, and compassionate.

Creating peace to prevent and resolve conflict is understood as-shulhu. Asshulhu can be pursued through conciliation, peacemaking, making a change or a reform that leads to the positive outcome, and the integrity to goodness and truth. Islam motivates its followers to involve in peace-making and consider it as goodness, not merely as an intervention or interference with a human affair. This concept can be applied in conflict among individuals, groups, and even countries; as-shulh also means peace agreement or pact.

Peace which is obtained by guaranteeing or maintaining security is known as al-amaanu. The implementation of al-amaan is not only measured from the absence of violence, but also the presence of trust or trustworthy. As nontraditional security defines peace freedom from fear and distrus. Al-amaanu is a form of peace that cannot be prevailed by an individu i, as as-shulhu. It needs the involvement of group of people, society, or perhaps larger body such as state in order to establish al-amaan.

The concept of peace in Islam; as-silmu, as-shulhu, and al-amaanu although generally they can be understood as 'peace'. However, they have different focuses, and perhaps intersect each other. The concept of peace in Islam might be relevant in providing an ideal image of the peace situation; positive. These concepts; although there may still be a number of concepts that resemble the concept of peace in Islam, these concepts have something in common with the concept of peacebuilding, peacemaking, and peacekeeping. All three are not a mechanism that must be passed in a certain phase of a peace attempt or conflict assessment to obtain certain results, but activities that are bound 
by values and divine rules. So, there is still a need for a deep study to form a conceptual framework consisting of a number of systematic mechanisms to achieve peace based on Islamic teaching.

\section{BIBLIOGRAPHY}

Abu-Sulayman, A. H. (1993). Towards an Islamic Theory of International Relations: New Directions for Islamic Methodology and Thought. International Institute of Islamic Thought (IIIT).

Abu-Zahrah, M. (1995). International Relations in Islam. Egypt: Daar al-Fikr al-Arabi.

Armstrong, K. (2001). Perang Suci: Dari Perang Salib Hingga Perang Teluk. Jakarta: Serambi Ilmu Semesta.

Burchill, S. (2005). Liberalism. In Theories of International Relations. New York: Palgrave Macmilan.

Donnelly, J. (2005). Realism. In Theories of International Relations. New York: Palgrave Macmilan.

Firestone, R. (1999). Jihad: The Origin of Holy War in Islam Reuven Firestone. New York: Oxford University Press.

Fuller, G. E. (2010). A World Without Islam. New York: Bacb Bay Books.

Galtung, J., \& Fischer, D. (2013). Johan Galtung: Pioneer of Peace Research. New York: Springer.

GPI. (2016). Global Peace Index 2016. Retrieved from https://reliefweb.int/ sites/reliefweb.int/files/resources/GPI 2016 Report_2.pdf

Guzzini, S. (2003). Realism in International Relations and International Political Economy: The Continuing Story of a Death Foretold. New York: Routledge.

Heywood, A. (2011). Global Politics. New York: Palgrave Macmillan.

Iqbal, A. (2000). Diplomasi Islam. (S. Rahman \& I. Sulaiman, Eds.). Jakarta: Pustaka Al-Kautsar.

Katsir, I. (2004a). Tafsir Ibnu Katsir. (M. A. Ghoffar, A. Muthi', A. I. Al-Atsari, \& M. Y. Harun, Eds.) (8th ed.). Bogor: Pustaka Imam As-Syafi'i.

------, (2004b). Tafsir Ibnu Katsir. (M. A. Ghoffar, A. Muthi', A. I. Al-Atsari, \& M. Y. Harun, Eds.) (1st ed.). Bogor: Pustaka Imam As-Syafi'i.

Khadduri, M. (1966). The Islamic Law of Nations: Shaybani's Siyar. Baltimore: The John Hopkins Press. 
Lapidus, I. M. (2002). A History of Islamic Societies. Second Edition. New York: Cambridge University Press.

Linklater, A. (2005). The English School. In Theories of International Relations. New York: Palgrave Macmilan.

Ma'luf, L. (2007). al-Munjid fi al-Lughah wa al-A'lam. Beirut: Dar al-Masyriq.

Munir, M. (2012). Islamic International Law (Siyar): An Introduction. Bepress.

Nimer, A. (2001). A Framework for Nonviolence and Peacebuilding in Islam. Journal of Law and Religion, 15(1), 217-265.

Pettiford, L. (2015). A New A-Z of International Relations Theory. London: I.B.Tauris.

Pratt, D. \& Woodlock, R. (2016). Fears of Muslims? International Perspective on Islamophobia. Switzerland: Springer International Publishing.

Sahide, A. (2018). Donald Trump; Islamic World and Globally Political Order of Indonesian Perspective. Istanbul: Proceeding of Academicsera International Conference.

Suryanegara, A. M. (2017). Api Sejarah. (N. Kurniawati, Ed.). Bandung: Suryadinasti.

Tamam, A. M. (2017). Islamic Worldview Paradigma Intelektual Muslim. Jakarta: Spirit Media Press. 